\title{
GMR
}

\section{Genotype $x$ environment interaction and its implication in identification of common bean populations with high calcium content}

\author{
S.B. Fernandes ${ }^{1}$, A.F.B. Abreu ${ }^{2}$ and M.A.P. Ramalho ${ }^{1}$ \\ ${ }^{1}$ Departamento de Biologia, Universidade Federal de Lavras, \\ Lavras, MG, Brasil \\ ${ }^{2}$ Embrapa Arroz e Feijão, Goiânia, GO, Brasil \\ Corresponding author: S.B. Fernandes \\ E-mail: samuelfernandes@agronomo.eng.br
}

Genet. Mol. Res. 15 (2): gmr.15028053

Received November 12, 2015

Accepted February 19, 2016

Published June 24, 2016

DOI http://dx.doi.org/10.4238/gmr.15028053

\begin{abstract}
The common bean is a food with high mineral content. Of the various types of beans cultivated in Brazil, carioca type beans are the most consumed. The aim of this study was to identify promising common bean populations with an emphasis toward the selection of carioca type bean lines with high calcium content. We also aimed to verify whether and how the crop season and the genotype (parental line and hybrid populations) $\mathrm{x}$ crop season interaction affect calcium content. A group of 3 lines of good agronomic characteristics were crossed with a group of 4 lines with high calcium content in a $3 \times 4$ partial diallel design. Great variability was identified among both the parental lines and the hybrid populations derived from the diallel crosses among the parental lines. We found significant interactions between crop season and both parental line and hybrid population. In the diallel analysis, only the general combining ability was significant, explaining $89.4 \%$ of the sum of squares. The RP-1, CNF05, and Safira lines exhibited the greatest calcium contents and a positive GCA. RP-1 is a line that presents high calcium content, in addition to having carioca type beans
\end{abstract}


and an upright plant with high yield. To further increase the calcium content of the RP-1 line, we suggest crossing it with the CNF05 and Safira lines. Although there was a hybrid population $\mathrm{x}$ crop season interaction, it was possible to identify populations that performed best in terms of calcium content in both crop seasons.

Key words: Minerals; Partial diallel; Nutritional quality

\section{INTRODUCTION}

The common bean, together with rice, is among the most commonly consumed foods in Brazil. This is true not only for the poorer social classes, but also for those with greater financial resources, who have become more and more concerned with having a healthy diet. These foods complement each other, because dry beans are low in sulfur-containing amino acids, which are present in rice. On the other hand, dry beans are high in lysine content, an amino acid not found in rice. Thus, the habit of the Brazilian people of ingesting rice with beans causes the biological value of the protein in the diet to approach that of animal-based proteins (Beninger and Hosfield, 2003; Broughton et al., 2003; Blair et al., 2009).

In addition to being an excellent source of protein, dry beans are rich in minerals, such as calcium, potassium, phosphorus, iron, copper, zinc, and magnesium (Mesquita et al., 2007; Ribeiro et al., 2008). Minerals in different quantities are necessary for the body and are essential for the performance of diverse functions. Among these minerals, calcium stands out due to its importance in bone and tooth formation, as well as its role in growth and its being a co-factor/regulator in various biochemical reactions (Franco, 1999; Miglioranza et al., 2003). The main sources of calcium are milk products. However, many people do not find milk products appetizing or are unable consume them due to lactose intolerance. It is estimated that $25 \%$ of the American population and $75 \%$ of adults throughout the world are lactose intolerant (Nicklas, 2003). For these people, beans are an excellent dietary alternative to dairy products since they contain a high quantity of calcium (Pennington, 1998; Frossard et al., 2000).

Using lines from the germplasm banks of institutions that work with genetic breeding of the common bean, many studies have demonstrated genetic variability in the traits that confer nutritional quality to the common bean and their modulation by the environment (Beebe et al., 2000; Mesquita et al., 2007; Ribeiro et al., 2008; Silva et al., 2012; Zacharias et al., 2012). Silva et al. (2012) evaluated 100 lines from the germplasm bank of the Federal University of Lavras (UFLA) and observed high variability in calcium content. However, the lines identified as having the greatest calcium content are typically poorly adapted and/or have agronomic characteristics and grain types that are not in agreement with the preferences of the consumers and farmers. In the case of grain type, the preference in Brazil is for carioca, which is characterized by a beige color with brown stripes. Thus, it would be preferable to obtain lines of the carioca type beans that show adaptation to the growth region, as well as high calcium content. For that reason, it is necessary to identify the most promising lines for use in hybridization and to concentrate efforts on the populations arising from crosses among these lines. A special emphasis should be placed on cases where the trait of interest relates to nutritional quality, which involves costly laboratory analyses.

There are various methodologies to identify the most promising parental lines and/or 
populations for obtaining breeding lines in autogamous plants (Ramalho et al., 2012). Among these, diallel crosses are often used in the common bean (Ramalho et al., 1988; Abreu et al., 1999; Mendes et al., 2009). However, no reports exist of the use of diallel crosses in breeding that focuses on increasing the calcium content of the bean grain.

In light of the above, the purpose of this study was to identify promising common bean populations and selecting lines with carioca type bean grains and high calcium content. We also investigated to what extent the crop season and the crop season $\mathrm{x}$ line and population interactions affect calcium content.

\section{MATERIAL AND METHODS}

The study was conducted in a greenhouse and laboratory of the Biology Department and Chemistry Department of the UFLA, in Lavras, MG, Brazil. Lavras is located at $21^{\circ} 14^{\prime}$ latitude South and $45^{\circ}$ longitude West at an average altitude of $910 \mathrm{~m}$. For lines with carioca grain type and good agronomic characteristics, we selected BRSMG Majestoso, MAII-22, and RP-1 (group 1). For the lines with high calcium content, but with grain type not in line with market standards, we used CNF05, Emgopa 201 - Ouro, Safira, and Fortuna 1895 (group 2). The lines with high calcium content were chosen based on a mineral content assessment including 100 lines from the UFLA common bean germplasm bank, carried out by Silva et al. (2012). These lines were sown in the 2010/2011 rainy season (sowing in October 2010). At the time of flowering, the two groups were then crossed in a $3 \times 4$ partial diallel design, resulting in 12 hybrid combinations. These seeds were used for the experiments conducted in the 2011 dry season (sowing in February) and in the 2011/2012 rainy season (sowing in October 2011).

The 12 hybrid populations obtained and the parental lines were assessed in a greenhouse. The experimental design was completely randomized with six replications. Each plot consisted of one pot with three plants/pot. At sowing, $20 \mathrm{~g}$ simple super phosphate, $7.5 \mathrm{~g}$ formulation 8-28-16 of N, $\mathrm{P}_{2} \mathrm{O}_{5}$ and $\mathrm{K}_{2} \mathrm{O}$ were used as fertilizer in each pot. Three top dress fertilizations were implemented as of the 20th day, each one with $0.74 \mathrm{~g}$ ammonium sulfate. Pots were irrigated automatically using microsprinklers every $3 \mathrm{~h}$ for a period of 5 min.

In each crop season, the collected seeds were dried in a laboratory oven at $65^{\circ} \mathrm{C}$ until $13 \%$ moisture was reached. The seeds were then ground in a micro-mill until a particle size of $<1 \mathrm{~mm}$ was achieved. The samples were then stored in marked impermeable popcorn bags sealed with adhesive tape and sent to the laboratory for further analysis. For determination of the calcium contents, nitric perchloric acid digestion was performed $\left(\mathrm{HNO}_{3}+\mathrm{HClO}_{4}\right.$, at a 3:1 ratio). The contents were quantified in a (flame) atomic absorption spectrophotometer using the procedures described by Malavolta et al. (1997).

The calcium contents of the hybrid populations and of the parental lines were subjected to individual and joint analysis of variance considering the completely randomized design with six replications, using SAS v. 9.0 (Statistical Analysis Systems, 2008). The model used in the joint analysis was as follows:

$$
Y_{i j k}=m+t_{i}+s_{j}+t s_{i j}+e_{i j k}
$$

(Equation 1)

in which:

$\mathrm{m}$ is the constant associated to all observations; 
$t_{i}$ is the effect of the $i^{\text {th }}$ treatment, with $i=1,2, \ldots, n$;

$s_{j}$ is the effect of the $j^{\text {th }}$ crop season, with $j=1,2$;

$\mathrm{ts}_{\mathrm{ij}}$ is the interaction between the $\mathrm{i}^{\text {th }}$ treatment and the $\mathrm{j}^{\text {th }}$ crop season. $\mathrm{j}^{\text {th }}$ crop season.

$\mathrm{e}_{\mathrm{ijk}}$ is the experimental error associated to the $\mathrm{k}^{\text {th }}$ observation of the $\mathrm{i}^{\text {th }}$ treatment in the

To meet the assumptions made by the analysis of variance, the data were Box and Cox (1964) transformed using R v. 3.0.3 (R Development Core Team, 2014). Mean values were compared using the cluster analysis method for grouping means (Scott and Knott, 1974) using the Genes software (Cruz, 2006).

The interaction between the hybrid populations and parental lines by crop season was broken down into the simple and complex part (Ramalho et al., 2012). Individual and joint diallel analysis was performed considering the two crop seasons using the mean calcium content data from each population. For this purpose, Griffing's (1956) method IV adapted to partial diallel analysis (Ferreira et al., 1993) was used.

\section{RESULTS}

The greatest source of variation in calcium content was crop season $(\mathrm{P}<0.001)$ (Table 1). The mean calcium content in the dry crop season was 2.6 times greater than that obtained in the rainy crop season (Table 2$)$. There was a significant difference among the parental lines ( $\mathrm{P}$ $=0.023)($ Table 1$)$. Although not statistically significant $(\mathrm{P}=0.078)$, the mean calcium content of group 2 lines was $8 \%$ greater than that of group 1 .

Table 1. Summary of joint analysis of variance of Box and Cox (1964) transformed common bean calcium content $(\mathrm{g} / \mathrm{kg})$ obtained in an assessment of 12 hybrid populations $\left(\mathrm{F}_{1}\right)$ and their parental lines in the 2011 dry and rainy crop season in Lavras, MG.

\begin{tabular}{l|c|c|c}
\hline Source of variation & d.f. & MS & P \\
\hline Treatment (Treat) & 18 & 25.59 & $<0.001$ \\
\hline F1 population & 11 & 36.49 & 0.001 \\
\hline Parental line & 6 & 9.33 & 0.023 \\
\hline Group 1 (G1) & 2 & 11.89 & 0.099 \\
\hline Group 2 (G2) & 3 & 5.41 & 0.363 \\
\hline G1 vs G2 & 1 & 15.96 & 0.078 \\
\hline Parental vs F1 & 1 & 3.25 & 0.423 \\
\hline Crop season (S) & 1 & 4245.80 & $<0.001$ \\
\hline Treat x S & 18 & 15.99 & $<0.001$ \\
\hline F1 x S & 11 & 19.11 & 0.001 \\
\hline Parental x S & 6 & 10.73 & 0.054 \\
\hline G1 x S & 2 & 21.47 & 0.098 \\
\hline G2 x S & 3 & 5.63 & 0.362 \\
\hline G1 vs G2 x & 1 & 4.28 & 0.358 \\
\hline Parental vs F1 x & 1 & 11.39 & 0.135 \\
\hline Error & 131 & 5.04 & \\
\hline Mean F1 & & $2.595^{*}$ & \\
\hline Mean G1 parental & & $2.300^{*}$ & \\
\hline Mean G2 parental & & $2.491^{*}$ & \\
\hline Grand mean & & $2.550^{*}$ & \\
\hline
\end{tabular}

*Means of the non-transformed data.

Significant differences in calcium levels were also observed among the $F_{1}$ hybrid populations $(\mathrm{P}<0.001)$ (Table 1). The lack of a parental line $v_{s} . \mathrm{F}_{1}$ source of variation suggests no heterosis. 
Table 2. Mean common bean calcium content $(\mathrm{g} / \mathrm{kg})$ obtained in the assessment of 12 hybrid populations and their parental lines in the 2011 dry and rainy crop season in Lavras, MG.

\begin{tabular}{l|l|c}
\hline & \multicolumn{2}{|c}{ Crop season } \\
\hline Parental lines/ F 1 & Dry & $1.067^{\mathrm{e}}$ \\
\hline Majestoso & $3.333^{\mathrm{b} *}$ & $1.433^{\mathrm{b}}$ \\
\hline RP-1 & $3.967^{\mathrm{b}}$ & $1.500^{\mathrm{b}}$ \\
\hline MAII-22 & $2.500^{\mathrm{c}}$ & $1.533^{\mathrm{b}}$ \\
\hline CNF05 & $3.700^{\mathrm{b}}$ & $1.500^{\mathrm{b}}$ \\
\hline Emgopa 201 - Ouro & $3.667^{\mathrm{b}}$ & $1.700^{\mathrm{b}}$ \\
\hline Safira & $2.833^{\mathrm{c}}$ & $1.567^{\mathrm{b}}$ \\
\hline Fortuna 1895 & $3.400^{\mathrm{b}}$ & $1.113^{\mathrm{e}}$ \\
\hline Majestoso x CNF05 & $4.510^{\mathrm{a}}$ & $1.175^{\mathrm{d}}$ \\
\hline Majestoso x Emgopa 201 - Ouro & $3.005^{\mathrm{c}}$ & $1.374^{\mathrm{c}}$ \\
\hline Majestoso x Safira & $3.574^{\mathrm{b}}$ & $2.048^{\mathrm{e}}$ \\
\hline Majestoso x Fortuna 1895 & $2.837^{\mathrm{c}}$ & $1.023^{\mathrm{a}}$ \\
\hline RP-1 x CNF05 & $4.558^{\mathrm{a}}$ & $1.279^{\mathrm{c}}$ \\
\hline RP-1 x Emgopa 201 - Ouro & $4.353^{\mathrm{a}}$ & $1.961^{\mathrm{a}}$ \\
\hline RP-1 x Safira & $4.324^{\mathrm{a}}$ & $1.548^{\mathrm{b}}$ \\
\hline RP-1 x Fortuna 1895 & $3.239^{\mathrm{c}}$ & $1.474^{\mathrm{b}}$ \\
\hline MAII-22 x CNF05 & $3.781^{\mathrm{b}}$ & $1.172^{\mathrm{d}}$ \\
\hline MAII-22 x Emgopa 201 - Ouro & $3.833^{\mathrm{b}}$ & $1.531^{\mathrm{b}}$ \\
\hline MAII-22 x Safira & $4.048^{\mathrm{b}}$ & $1.824^{\mathrm{a}}$ \\
\hline MAII-22 x Fortuna 1895 & $2.948^{\mathrm{c}}$ & 1.464 \\
\hline Mean & 3.744 & \\
\hline
\end{tabular}

*Means followed by the same letter within each column are not significantly different (Scott and Knott, 1974) at the $5 \%$ probability level.

The treatment $\mathrm{x}$ crop season interaction was significant $(\mathrm{P}<0.001)$. Through breakdown of the interaction into its simple and complex parts, it was possible to verify that it was predominantly complex $(74 \%)$. However, in group 2, the crop season x parental line interaction was not found (Table 1). In support of this, the calcium contents of group 2 remained constant across both crop seasons, as shown in the Scott and Knott (1974) grouping test (Table 2). In the case of the hybrid populations, the interaction with crop season was significant, as can be seen in the within hybrid population variation in calcium content among crop seasons (Table 2).

In the diallel analysis, a significant effect $(\mathrm{P} \leq 0.05)$ was observed for the general combining ability (GCA) of groups 1 and 2 (Table 3 ). The proportion of the sum of squares explained by the GCA of groups 1 and $2\left(\mathrm{R}^{2}\right)$ was $89.4 \%$, while the specific combining ability (SCA) explained only $10.6 \%$ (Table 3 ). This reinforces our finding that heterosis does not occur on this trait.

Table 3. Summary of joint partial diallel analysis of calcium content $(\mathrm{g} / \mathrm{kg})$ in common bean obtained in the assessment of 12 hybrid populations in the 2011 dry and rainy crop season in Lavras, MG.

\begin{tabular}{l|c|c|c}
\hline Source of variation & d.f. & MS & $\mathrm{R}^{2}$ \\
\hline Crop season & 1 & $3387.99^{* *}$ & \\
\hline F1 population & 11 & $34.36^{* *}$ & 55.0 \\
\hline GCA I & 2 & $103.99^{* *}$ & 34.4 \\
\hline GCA II & 3 & $43.32^{* *}$ & 10.6 \\
\hline SCA & 6 & $6.67 \mathrm{~ns}$ & \\
\hline F1 X Crop season (S) & 11 & $18.39^{* *}$ & \\
\hline GCA I x S & 2 & $16.99^{*}$ & \\
\hline GCA II x S & 3 & $23.08^{* *}$ & \\
\hline SCA x S & 6 & $16.51^{* *}$ & \\
\hline Error & 105 & 5.54 & \\
\hline
\end{tabular}

***Significant at 5 and $1 \%$ probability levels, respectively; ns = not significant; GCA = General Combining Ability; SCA = Specific Combining Ability. 
The GCA estimates $\left(g_{\mathrm{i}}\right)$ for each parental line are presented in Table 4. It may be observed that, among the lines of carioca type grains (group 1), RP-1 appears to be most promising because it presented the greatest $\mathrm{g}_{\mathrm{i}}$ estimate in both crop seasons. Similarly, in group 2, the parental lines Safira and CNF05 stood out as having relatively higher $\mathrm{g}_{\mathrm{i}}$ estimates. It may be observed that these three parental lines also were among those showing the best per se performance in terms of calcium contents (Table 2). The high performance of the parental lines RP-1, Safira, and CNF05 in the hybrid populations is illustrated by the high mean values of calcium content presented in Table 2. The two populations with the greatest mean value in both crop seasons as well as on average over both crop seasons were those derived from crosses between RP-1 and the Safira and CNF05 lines.

Table 4. Estimates of general $\left(\mathrm{g}_{\mathrm{i}}\right)$ and specific $\left(\mathrm{s}_{\mathrm{ij}}\right)$ combining ability and respective standard deviations $(\mathrm{SD})$ as well as the standard deviation for the comparison between specific combining ability with a common genitor of group $1\left(\mathrm{~S}_{\mathrm{ij}}-\mathrm{S}_{\mathrm{ik}}\right)$, with a common genitor of group $2\left(\mathrm{~S}_{\mathrm{ij}}-\mathrm{S}_{\mathrm{kj}}\right)$ and for specific combining ability of individuals with no common genitors for calcium content $\mathrm{SD}\left(\mathrm{S}_{\mathrm{ij}}-\mathrm{S}_{\mathrm{kl}}\right)(\mathrm{g} / \mathrm{kg})$ obtained in the assessment of 12 common bean populations derived from hybridization among three lines of carioca type grains (group 1) and four lines with high calcium content (group 2) in the 2011 dry and rainy crop season in Lavras, MG.

\begin{tabular}{|c|c|c|c|c|}
\hline & \multicolumn{4}{|c|}{ Dry } \\
\hline Parental line & BRSMG Majestoso & RP-1 & MAII-22 & $\mathrm{g}_{\mathrm{i}}$ group 2 \\
\hline CNF05 & 0.151 & -0.022 & -0.129 & 0.147 \\
\hline Emgopa 201 - Ouro & -0.137 & 0.057 & 0.080 & -0.011 \\
\hline Safira & -0.038 & -0.005 & 0.043 & 0.076 \\
\hline Fortuna 1895 & 0.024 & -0.030 & 0.006 & -0.212 \\
\hline \multirow[t]{2}{*}{$\mathrm{g}_{\mathrm{i}}$ group 1} & -0.087 & 0.125 & -0.038 & \\
\hline & \multicolumn{4}{|c|}{ Rainy } \\
\hline CNF05 & -0.105 & 0.164 & -0.059 & 0.051 \\
\hline Emgopa 201 - Ouro & 0.194 & -0.113 & -0.081 & -0.184 \\
\hline Safira & 0.046 & 0.046 & -0.092 & 0.133 \\
\hline Fortuna 1895 & -0.135 & -0.097 & 0.232 & 0.001 \\
\hline $\mathrm{g}_{\mathrm{i}}$ group 1 & -0.233 & 0.184 & 0.049 & \\
\hline
\end{tabular}

Dry: Group 1: SD $\left(g_{j}\right)=0.050 ; \mathrm{SD}\left(\mathrm{g}_{\mathrm{i}}-\mathrm{g}_{\mathrm{i}}\right)=0.086$; Group 2: SD $\left(\mathrm{g}_{\mathrm{i}}\right)=0.061 ; \mathrm{SD}\left(\mathrm{g}_{\mathrm{i}}-\mathrm{g}_{\mathrm{i}}\right)=0.100 ; \mathrm{SD}\left(\mathrm{s}_{\mathrm{ij}}\right)=0.037$; $\mathrm{SD}\left(\mathrm{S}_{\mathrm{ij}}-\mathrm{S}_{\mathrm{ik}}\right)=0.061 ; \mathrm{SD}\left(\mathrm{S}_{\mathrm{ij}}-\mathrm{S}_{\mathrm{kj}}\right)=0.064 ; \mathrm{SD}\left(\mathrm{S}_{\mathrm{ij}}-\mathrm{S}_{\mathrm{kl}}\right)=0.048$. Rainy: Group 1: SD $\left(\mathrm{g}_{\mathrm{i}}\right)=0.032 ; \mathrm{SD}\left(\mathrm{g}_{\mathrm{i}}-\mathrm{g}_{\mathrm{i}}\right)=0.056$; Group 2: $\mathrm{SD}\left(\mathrm{g}_{\mathrm{i}}\right)=0.040 ; \mathrm{SD}\left(\mathrm{g}_{\mathrm{i}}-\mathrm{g}_{\mathrm{i}}\right)=0.065 ; \mathrm{SD}\left(\mathrm{s}_{\mathrm{ij}}\right)=0.024 \mathrm{SD}\left(\mathrm{S}_{\mathrm{ij}}-\mathrm{S}_{\mathrm{ik}}\right)=0.039 ; \mathrm{SD}\left(\mathrm{S}_{\mathrm{ij}}-\mathrm{S}_{\mathrm{kj}}\right)=0.042 ; \mathrm{SD}$ $\left(\mathrm{S}_{\mathrm{ij}}-\mathrm{S}_{\mathrm{kl}}\right)=0.031$.

\section{DISCUSSION}

Up to $81 \%$ of the calcium content in the common bean seed is concentrated in the seed coat (Singh et al., 1968; Lombardi-Boccia et al., 1998; Moraghan et al., 2006). As the seed coat, which is maternal tissue, and the embryo and cotyledon, which are products of crosses, represent different generations, in this study we used the seed coat generation as a reference for the assessment of the calcium content in bean grains. Thus, as seeds were collected from $F_{1}$ plants, the generation of the seed coat is $F_{1}$. It could be argued that variation in the amount of calcium in the embryo and/or cotyledon could also affect the results. However, the mean values used in the diallel analysis were based on at least 1200 bean grains, i.e., 18 plants/ treatment with approximately 65 bean grains/plant. Under these conditions, there is probably little variation in calcium content within the $\mathrm{F}_{2}$ generation, and we therefore argue that the samples can indeed be considered representative of the $\mathrm{F}_{1}$ generation.

The significant effect of the crop season was an expected result because it is evident that the environmental conditions among crop seasons vary a lot. Even though the present 
study was conducted in a greenhouse, which increases the environmental homogeneity, it is important to note that screen coverage does not impede the passage of rainwater. In addition, the temperature and relative humidity in the rainy crop season are greater than those of the dry crop season.

The variability identified among the parents of group 1 should be highlighted, where the RP-1 line stood out with its high mineral content (Table 2). The parental lines of this group were included in the diallel for having carioca type grains and good agronomic characteristics, regardless of calcium content. The significant crop season $\mathrm{x}$ parental line interaction confirmed that the lines respond differently under different environmental conditions. This result has also been found in several previous studies (Quenzer et al., 1978; Barampama and Simard, 1993; Quintana et al., 1999; Ramalho et al., 2012). In principle, it may be said that the presence of this interaction is unfavorable for selection, because the classification of the genotypes varies among different environments (Ramalho et al., 1988). However, the mineral content in the group 2 lines was practically constant within the Scott and Knott (1974) groupings across both crop seasons, indicating that these lines maintain their high nutritional value even across environments.

In the diallel analysis, it was shown that the parents of the two groups differed with regard to the frequency of favorable alleles for calcium content, as suggested by the significant effect of GCA (Table 3). The results from the diallel analysis confirmed a predominance of additive effects in the control of calcium content, since the proportion of the sum of squares explained by the GCA of groups 1 and 2 was nine times greater than that explained by the SCA (Table 3). This was also supported by the contrast between the parents and $F_{1}$. The fact that the parents did not differ significantly in SCA also confirms the predominance of additive effects (Ramalho et al., 1988; Cruz et al., 2004; Lorencetti et al., 2005). In this case, the ideal approach is to perform crosses only between good parental lines, to the extent possible (Ramalho et al., 1988; Dudley, 1997; Rasmusson and Phillips, 1997).

In the present study, the parental lines of group 1 were chosen for having carioca type grains and good agronomic characteristics. However, it was also seen that some of these parental lines also contributed to increasing the calcium content of the hybrid populations. This fact is for example illustrated by the high mean calcium content observed in the RP-1 cultivar of group 1, which was comparable to that of the parental lines that were initially classified as having a high mineral content (Table 2). It is important to note that the RP-1 line, in addition to having carioca type grains, stood out for its grain yield and predominantly upright plant architecture in the assessments conducted in Minas Gerais (unpublished results), where it is in the process of being registered for growth in the state. Thus, the results obtained here are promising due to the possibility of joining one more desirable phenotype, high calcium content, to those already exhibited by the RP-1 line. To increase the calcium content of the RP-1 line even more, the best option is crossing it with the CNF05 and Safira lines. Although there was a significant hybrid population x crop season interaction, the populations derived from the crosses mentioned above showed the highest performance in both crop seasons (Table 2).

\section{Conflicts of interest}

The authors declare no conflict of interest. 


\title{
ACKNOWLEDGMENTS
}

\author{
Research supported by CAPES, FAPEMIG, and CNPq.
}

\section{REFERENCES}

Abreu AFB, Ramalho MAP and Ferreira DF (1999). Selection potential for seed yield from intra and inter-racial populations in common bean. Eyphytica 108: 121-127. http://dx.doi.org/10.1023/A:1003608310384

Barampama Z and Simard RE (1993). Nutrient composition, protein quality and antinutritional factors of some varieties of dry beans (Phaseolus vulgaris) grown in Burundi. Food Chem. 47: 159-167. http://dx.doi.org/10.1016/0308$\underline{8146(93) 90238-\mathrm{B}}$

Beebe S, Gonzalez AV and Rengifo J (2000). Research on trace minerals in the common bean. Food Nutr. Bull. 21: 387391. http://dx.doi.org/10.1177/156482650002100408

Beninger CW and Hosfield GL (2003). Antioxidant activity of extracts, condensed tannin fractions, and pure flavonoids from Phaseolus vulgaris L. seed coat color genotypes. J. Agric. Food Chem. 51: 7879-7883. http://dx.doi.org/10.1021/ if0304324

Blair MW, Astudillo C, Grusak MA, Graham R, et al. (2009). Inheritance of seed iron and zinc concentrations in common bean (Phaseolus vulgaris L.). Mol. Breed. 23: 197-207. http://dx.doi.org/10.1007/s11032-008-9225-Z

Box GEP and Cox DR (1964). An analysis of transformations. J. R. Stat. Soc. [Ser A] 26: 211-252.

Broughton WJ, Hernández G, Blair M, Beebe S, et al. (2003). Beans (Phaseolus spp) - model food legumes. Plant Soil 252: 55-128. http://dx.doi.org/10.1023/A:1024146710611

Cruz CD (2006). Programa Genes: Estatística experimental e matrizes. UFV, Viçosa.

Cruz CD, Regazzi AJ and Carneiro PCS (2004). Modelos biométricos aplicados ao melhoramento genético. 3rd ed. UFV, Viçosa.

Dudley JW (1997). Quantitative genetics and plant breeding. Adv. Agron. 59: 1-23. http://dx.doi.org/10.1016/S0065$\underline{2113(08) 60051-6}$

Ferreira DF, Rezende GDSP and Ramalho MAP (1993). An adaptation of Griffing's method IV of complete diallel cross analysis for experiments repeated in several environments. Braz. J. Genet. 16: 357-366.

$<$ unknown>Franco G (1999). Tabela de composição química dos alimentos. 9th edn. Atheneu, Rio de Janeiro.</unknown>

Frossard E, Bucher M, Mächler F, Mozafar A, et al. (2000). Potential for increasing the content and bioavailability of Fe, $\mathrm{Zn}$ and $\mathrm{Ca}$ in plants for human nutrition. J. Agric. Food Chem. 80: 861-879. http://dx.doi.org/10.1002/(SICI)10970010(20000515)80:7<861::AID-JSFA601>3.0.CO;2-P

Griffing B (1956). Concept of general and specific combining ability in relation to diallel crossing systems. Aust. J. Biol. Sci. 9: 463-493.

Lombardi-Boccia G, Lucarini M, Di Lullo G, Del Puppo E, et al. (1998). Dialysable, soluble and fermentable calcium from beans (Phaseolus vulgaris L.) as model for in vitro assessment of the potential calcium availability. Food Chem. 61: 167-171. http://dx.doi.org/10.1016/S0308-8146(97)00040-X

Lorencetti C, Carvalho FIF, Benin G, Marchioro VS, et al. (2005). Capacidade combinatória e heterose em cruzamento dialélico de aveia (Avena sativa L.). R. Bras. Agrociencia 11: 143-148.

Malavolta E, Vitti GC and Oliveira AS (1997). Avaliação do estado nutricional das plantas: princípios e aplicações. 2nd ed. Potafos, Piracicaba.

Mendes FF, Ramalho MAP and Abreu AFB (2009). Índice de seleção para escolha de populações segregantes de feijoeirocomum. Pesquisa Agropecu. Bras. 44: 1312-1318. http://dx.doi.org/10.1590/S0100-204X2009001000015

Mesquita FR, Corrêa AD, Abreu CMP, Lima RAZ, et al. (2007). Linhagens de feijão (Phaseolus vulgaris L.): composição química e digestibilidade proteica. Cienc. Agrotec. 31: 1114-1121. http://dx.doi.org/10.1590/S1413$\underline{70542007000400026}$

Miglioranza E, de Araujo R, Endo RM, de Souza JRP, et al. (2003). Teor de cálcio em frutos de diferentes cultivares de feijão-vagem. Hortic. Bras. 21: 158-161. http://dx.doi.org/10.1590/S0102-05362003000200007

Moraghan JT, Etchevers JD and Padilha J (2006). Contrasting accumulations of calcium and magnesium in seed coats and embryos of common bean and soybean. Food Chem. 95: 554-561. http://dx.doi.org/10.1016/j.foodchem.2004.10.060

Nicklas TA (2003). Calcium intake trends and health consequences from childhood through adulthood. J. Am. Coll. Nutr. 22: 340-356. http://dx.doi.org/10.1080/07315724.2003.10719317

Pennington J (1998). Bowe's \& Church's food values of portions commonly used. 17th ed. Lippincott, Philadelphia.

Quenzer NM, Huffman VL and Burns EE (1978). Some factors affecting pinto bean quality. J. Food Sci. 43: 1059-1061. 
http://dx.doi.org/10.1111/j.1365-2621.1978.tb15232.x

Quintana JM, Harrison HC, Nienhuis J, Palta JP, et al. (1999). Comparison of pod calcium concentration between two snap bean populations. J. Am. Soc. Hortic. Sci. 124: 273-276.

R Development Core Team (2014). R: A language and environment for statistical computing. R Foundation for Statistical Computing. Available at [http://www.R-project.org/]. Accessed July 20, 2012.

Ramalho MAP, Santos JB and Pereira Filho IA (1988). Choice of parents for dry bean (Phaseolus vulgaris L.) breeding. I. Interactions of mean components by generation and by location. Rev. Bras. Genet. 11: 391-400.

Ramalho MAP, Abreu AFB, Santos JB and Nunes JAR (2012). Aplicações da genética quantitativa no melhoramento de plantas autógamas. 1st ed. UFLA, Lavras.

Rasmusson DC and Phillips RL (1997). Plant breeding progress and genetic diversity from de novo variation and elevated epistasis. Crop Sci. 37: 303-310. http://dx.doi.org/10.2135/cropsci1997.0011183X003700020001x

Resende MDV and Duarte JB (2007). Precisão e controle de qualidade em experimentos de avaliação de cultivares. Pesq. Agropec. Trop 37: 182-194.

Ribeiro ND, Jost E, Cerutti T, Mazieiro SM, et al. (2008). Composição de microminerais em cultivares de feijão e aplicações para o melhoramento genético. Bragantia 67: 267-273. http://dx.doi.org/10.1590/S0006-87052008000200002

Scott AJ and Knott MA (1974). A cluster analysis method for grouping means in the analysis of variance. Biometrics 30 : 507-512. http://dx.doi.org/10.2307/2529204

Silva CA, Abreu AFB, Ramalho MAP and Maia LGS (2012). Chemical composition as related to seed color of common bean. Crop Breed. Appl. Biotechnol. 12: 132-137. http://dx.doi.org/10.1590/S1984-70332012000200006

Singh S, Singh HD and Sikka KC (1968). Distribution of nutrients in the anatomical parts of common Indian pulses. Cereal Chem. 45: 13-18.

Statistical Analysis Systems (2008). SAS/STAT® 9.2 User's Guide. Version 9.2. SAS Institute Inc., Cary.

Zacharias J, Leilani A, Jacob D, Miklas PN, et al. (2012). Genetic variability of mineral composition in common bean seed. Annu. Rep. Bean Improv. Coop. 55: 59-60. 